\title{
Abandoning the Concept of Renewable Energy
}

\author{
Atte Harjanne [1, 2], Janne M. Korhonen [3] \\ [1] Aalto University School of Business \\ [2] Finnish Meteorological Institute \\ [3] Turku School of Economics \\ Corresponding author: Atte Harjanne / atte.harjanne@aalto.fi
}

Published as

Harjanne, A. \& Korhonen, J. M. (2019). Abandoning the concept of renewable energy

Energy Policy 127, 330-340.

https://doi.org/10.1016/j.enpol.2018.12.029

\begin{abstract}
Renewable energy is a widely used term that describes certain types of energy production. In politics, business and academia, renewable energy is often framed as the key solution to the global climate challenge. We, however, argue that the concept of renewable energy is problematic and should be abandoned in favor of more unambiguous conceptualization.

Building on the theoretical literature on framing and based on document analysis, case examples and statistical data, we discuss how renewable energy is framed and has come to be a central energy policy concept and analyze how its use has affected the way energy policy is debated and conducted. We demonstrate five major issues with the concept of renewable energy: i) renewability does not guarantee sustainability; ii) renewables encompass very different forms of energy, with very different policy challenges; iii) policies based on renewable energy have mixed results; iv) the concept of renewable energy enables environmentally harmful bait-and-switch; and v) the whole idea of renewable energy is misleading. After analyzing these issues, we discuss alternative conceptualizations and present our model of categorizing energy production according to carbon content and combustion.
\end{abstract}

The paper does not intend to criticize or promote any specific form of energy production, but instead discusses the role of institutional conceptualization in energy policy.

\section{Highlights}

- Renewable energy (RE) is a widely shared concept that influences energy policy worldwide

- The concept of RE is problematic in many ways, yet these problems are often ignored

- The umbrella of RE seems to enable questionable bait-and-switch tactics

- Alternative conceptualization of energy could support more effective climate policy

\section{Key words}

Renewable energy, energy policy, climate change, institutional theory, framing 


\section{Acknowledgements}

The authors would like to thank Ben Heard and Nina Granqvist for their invaluable comments during the writing process.

\section{Funding}

This work was supported by the Jenny and Antti Wihuri Foundation.

\section{Declaration of interest}

Declarations of interest: none

\section{Introduction}

"The limits of my language mean the limits of my world." wrote Ludwig Wittgenstein. Today, the limits of our language limit our efforts to combat climate change. Shared meanings and concepts are the building blocks used to debate and create policies. Problems and limitations within those meanings and concepts are reflected in the policies and their results. Imprecise language can lead to ambiguity in energy policy (Littlefield 2013; Evensen et al. 2014), and ambiguity may be a luxury we can no longer afford.

Mitigating climate change without sentencing the poor globally to perpetual poverty is the prime challenge of energy policy today. Our civilization relies heavily on fossil energy, with around 80 percent of primary energy coming from fossil fuels (IEA 2017a). Their combustion is contributing to a rapid increase in the average temperature of our planet. Continued large-scale exploitation of fossil fuels creates grave risks for human civilization, yet sustaining and extending a prosperous civilization requires a certain level of energy supply.

One of the most commonly touted solutions to this dilemma is renewable energy. Instead of relying on depleting stocks of buried energy relics, the narrative behind the renewable energy solution states that we should power our societies by harnessing renewable natural energy flows. Given the increasing awareness of climate change, the concept of renewable energy has become such a powerful and universal "focusing device" (Rosenberg 1976) that it has been adopted in climate and energy strategies and has been guiding policy worldwide (IEA 2018a).

The benefits, challenges and economic feasibility of fully renewable energy systems have been debated in many earlier papers (see, e.g. Jacobson and Delucchi 2011; Trainer 2012; Brook and Bradshaw 2014; Heard et al. 2017). Our aim instead is to problematize the whole concept of renewable energy as it exists today in the field of energy policy. However, the target of the problematization is not renewable energy generation or any specific policy; rather, we argue that the problem is in the conceptual framing of energy sources as either renewable or non-renewable.

This paper is anchored in institutional theory. We answer the call made by Ansari et al. (2011) on how social scientists can contribute to managing climate change by enhancing its vocabulary and providing useful explanations; or, as in our case, by pointing out the problems with the existing vocabulary. 
Institutional theory offers useful frameworks for studying energy policy and the transformation currently taking place in global energy use and production. It focuses on the emergence, development and impact of institutions - resilient social structures such as organizations, norms or rules (Scott 2008). Institutions emerge and are formed around socially constructed, shared meanings (DiMaggio and Powell 1983; Scott 1995; Thornton and Ocasio 1999). A popular level of institutional analysis is the level of organizational fields (DiMaggio and Powell 1983; Scott 1995) that consist of actors in a recognized area of institutional life and follow certain institutional logics (Thornton and Ocasio 1999). Grand challenges such as climate change are complex, uncertain and evaluative problems of major societal significance (Ferraro et al. 2015), and as such are typically not an issue at the level of individual organizations, but are encountered in the field (Grodal and O’Mahony 2017).

Framing is a process where meanings are constructed (Benford and Snow 2000). Originally introduced by Goffman (1974), frames can be considered models of interpretation which enable the organization of experiences and occurrences into communicable sets of shared beliefs and meanings that also guide action (Benford and Snow 2000). Frames are thus essential for the formation and maintenance of institutional logic as well. Frames and framing have mostly been applied in research on social movements, where the interest typically is the role of frames in inspiring and legitimating actions and for mobilizing resources (Benford and Snow, 2000; Granqvist and Laurila 2011). Among science and technology studies, Rosenberg's (1976) idea of "focusing devices" that direct research and policy efforts towards a specific subset of technologies, sometimes at the expense of other subsets, resonates with this idea of a framing process. The nature of framing also includes drawing boundaries between what is included in a shared meaning and what is not, and can result in umbrella constructs (Hirsch and Levin 1999) that organize various theoretical elements of a field into a meaningfully combined concept.

In this paper, we approach the concept of renewable energy as a socially constructed result of framing in the field of energy policy. Since frames are fundamentally constructed in discursive processes (Benford and Snow 2000) we focus our attention mainly on language and written documents, although we briefly discuss visual discourse (see, e.g. O'Neill and Smith 2014) as well. Discourse analysis has been widely used in studying the formation of environmental and energy policies (see, e.g. Hajer and Versteeg 2005; Jessup 2010; Cotton et al. 2014), and the role of linguistic framing and discourse in energy policy has been discussed in detail by Scrase and Ockwell (2010), who described how framing may serve to sustain the continuation of existing policy positions. It should be noted that while we rely on theory of framing, we refer to renewable energy also as a "concept", since we believe that this term is more familiar to most audiences.

The focus of this paper, however, is not to elaborate the theoretical foundations, but instead to employ these concepts from organizational science to analyze the role and impact of the shared concept of renewable energy in energy policy. In doing this, we combine both qualitative and quantitative data and draw on material from a broad selection of public documents, statistics and academic and grey literature. Using case examples, we first describe the shared concept of renewable energy and then problematize it based on a synthesis of available societal, technical and economic data.

The paper is structured as follows. After the introduction we briefly outline the history of the concept of renewable energy. In the second section we discuss the current status of the concept and in the third its use. The fourth section goes through the main problems we identify related to the current 
conceptualization of renewable energy. In the fifth section we discuss the implications of the problems and alternative conceptualizations, before concluding the paper in the sixth section.

\section{A Brief History of Renewable Energy}

The history of renewable energy as a concept predates current climate awareness and mitigation debates. This explains, to some extent, why the concept is problematic in today's context. Therefore, understanding the framing process and the history of the concept is useful.

In English-language scientific and technical literature, the term "renewable energy" has been used as a contrast to exhaustible fossil fuel sources, at least since the early 1900s (Bell 1906; Clarke et al. 1909). Interestingly, some early analyses made a distinction between "renewable" and "inexhaustible" energy sources, referring to animal power sources and wood as "renewable" while classifying solar radiation, wind, tidal and hydropower as "inexhaustible" instead (Clarke et al. 1909). Even then, the context for using this term was to oppose or at least provide an alternative to society's dependence on fossil fuels, although the rationale was not overuse as today but predicted exhaustion. Therefore, it is not surprising that discussions about "renewable energy" became more common during the Second World War, as can be seen from the occurrence of the term in the digitized corpus of Google Books (Fig. 1).

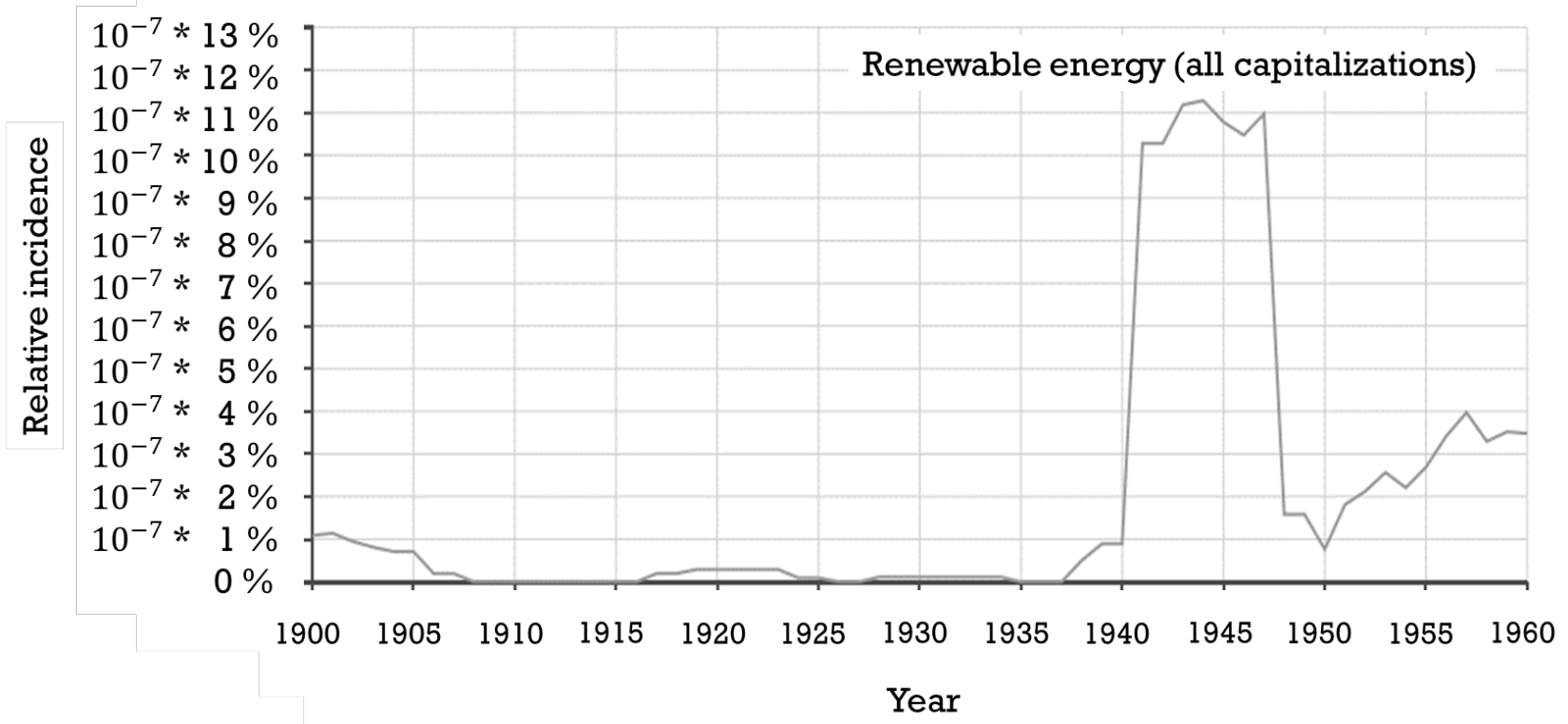

Figure 1. Relative incidence of term "renewable energy" in Google Books corpus, 1900-1960, variations in capitalization ("renewable energy", "Renewable Energy", etc.) included.

However, the term acquired its modern meaning and many of the current political connotations during the energy debates of the 1970s. The counterculture and early environmental movements of the 1960s latched on to "renewable energy" as a conceptual alternative to perceived dehumanizing, environmentally destructive "centralized" energy sources, such as coal and nuclear power.

Because these early conflicts were instrumental in the way the entire environmental discourse was subsequently framed, the debate between the supporters of two different "energy paths", to borrow a 
term from an enormously influential 1976 article by Amory Lovins (Lovins 1976), still influences practically all environmental discourse today. The supporters of the "soft path", which called for more decentralized, small-scale energy generation, including but not limited to renewable energy sources as we now understand the term (see also the very influential "Small is Beautiful" ideology originating from Schumacher 1973), were, for the most part, synonymous with the early environmental activists, whereas the "traditional" or "hard" path was presented as the status quo.

During these 1970s debates, the nascent environmental movement cemented its attitude towards "good" and "bad" energy sources. In particular, the 1970s environmental movement abandoned the 1950 s and 1960s environmental conservation movements' acceptance of nuclear power. Earlier generations had seen nuclear power as an environmentally benign alternative to massive hydropower projects (see, e.g. Särkikoski 2011), but growing distrust with "establishment" science and engineering and with large-scale, top-down, undemocratic projects caused the environmental movement at large to reverse its hitherto lukewarm acceptance (Kirk 2001; Pearce 1991). Frustration with lack of progress in nuclear disarmament and a perceived lack of democratic control over nuclear arsenals might have also contributed to nuclear energy in general becoming a sort of proxy target for erstwhile anti-nuclear weapons protesters (Weart 2012).

Irrespective of the precise social and political circumstances of the time, the battle lines were drawn: in practically all subsequent environmental discourse, energy sources have been divided between "good" (solar, wind, tidal, geothermal, biomass, and with some reservations hydropower), "tolerable for time being" (small scale use of fossil fuels and peat), and "bad" - large-scale, centralized power plants, most notably nuclear power. By and large, these divisions have prevailed ever since, although realities of climate change have generally caused the environmental movement of today to reduce its 1980sera tolerance of coal, gas and peat as "bridge" fuels to be used until such time as the world is ready for totally renewable energy system (for historical examples of this acceptance and discussion in the US and UK, see e.g. Schumacher 1973; Lovins 1976; Pearce 1991).

As we go on to demonstrate in this paper, the problem with this forty-year old concept is that the world of 2018 is not the same as the world of 1978. Nevertheless, the concept of renewable energy is still routinely used in energy policy, as we discuss in the next section. Figure 2 shows how the term has gained increasing currency steadily over the last three decades. 


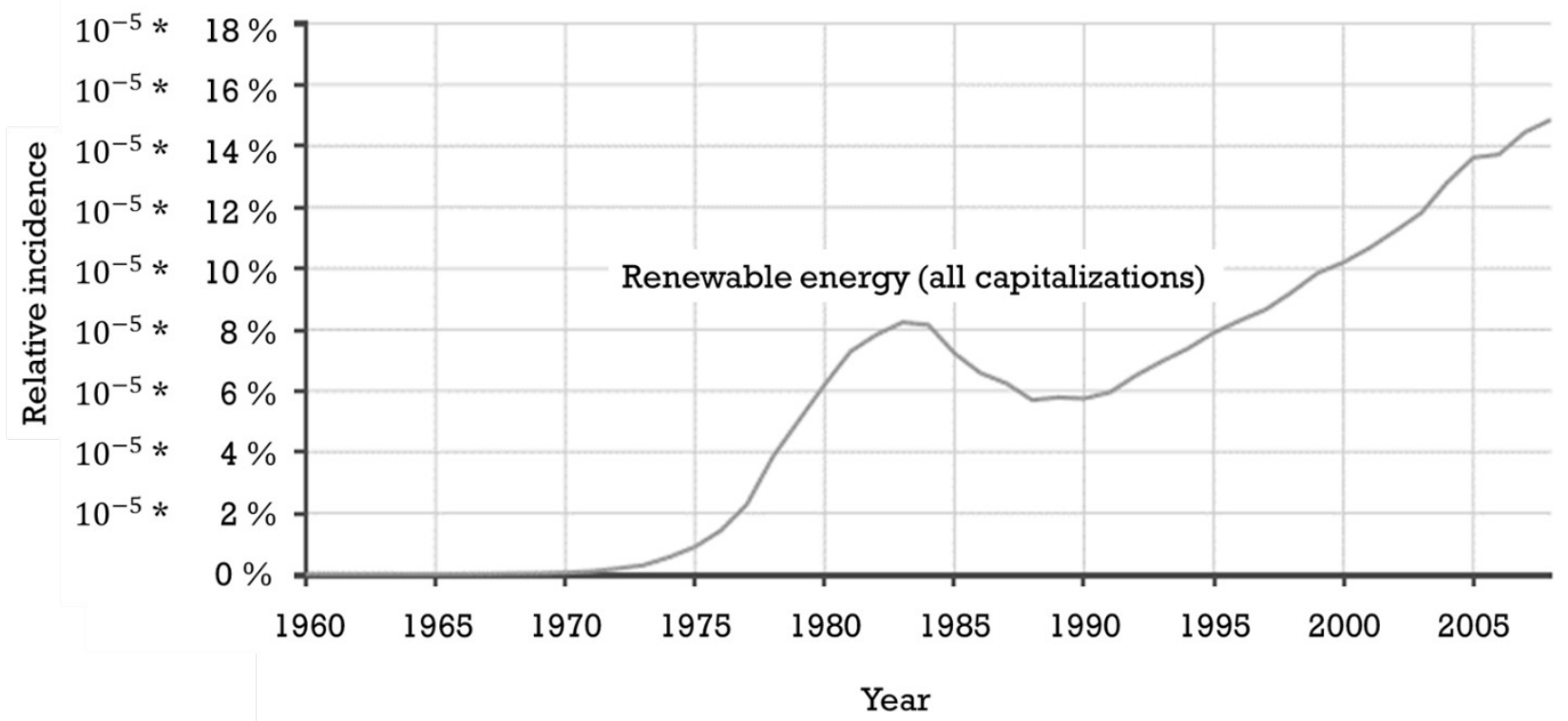

Figure 2. Relative occurrence of phrase "renewable energy" in Google's corpus of digitized books 1960-2010, all variations in capitalization included.

\section{The Concept in Use}

The definition of renewable energy is largely uncontested and there is broad agreement on what is considered to be renewable energy. The International Energy Agency (IEA) defines renewable energy as "energy derived from natural processes that are replenished at a faster rate than they are consumed", and mentions solar, wind, geothermal, hydro and biomass as examples of renewable energy (IEA 2018b). The European Union includes wind, solar, hydro and tidal power, geothermal energy, biofuels and the renewable part of waste as renewable energy in its statistical accounting (Eurostat 2018a); in a recent report, the United Nations Environment Programme follows the same logic (Frankfurt School 2018).

This consistency is atypical among popular concepts related to different grand challenges. In comparison, the exact definitions of concepts such as sustainability (Kates et al. 2005), cleantech (Caprotti 2012) or corporate social responsibility (Dahlsrud 2006) have been extensively researched and interrogated with far lesser convergence of definition.

Our general claim is that renewable energy has become an important concept within the fields of energy policy and climate change mitigation, and has a central role in driving the logics within these fields. The popularity of the concept in itself would make it a huge effort to comprehensively map the current use of the term. Thus we demonstrate the use and spread of the concept with the following examples.

The European Union (EU) energy policy is an example from the international political domain of how the concept of renewable energy has been adopted. Promoting renewable energy is one of the cornerstones of the energy policy of the European Union. In 2009, EU put in place the so-called 
Renewable Energy Directive, which mandates that by the year 2020 one-fifth of the total energy needs within the union must come from renewable energy (EU 2009). The directive is currently being revised, with a planned goal of reaching 27 percent share for renewable energy by 2030 (EU 2018).

Beyond the directive, EU has also developed an Energy Roadmap looking toward the year 2050 (European Commission 2011). The roadmap is not legally binding and presents five alternative scenarios for decarbonization. Renewables play a major role, as their share of final energy consumption is at least 55 percent in all the scenarios. The specific "High Renewable energy sources" scenario reaches 75 percent share in total energy consumption and 97 percent share in electricity consumption.

These policies and communications show that the concept of renewable energy is essential in EU policy and that EU is strongly committed to promoting renewable energy. It is even reasonable to claim that for the union, renewable energy is not only a means to combat climate change, but is an end in itself. This is highlighted by the will to set renewable target policies that overlap and are likely to hinder the effectiveness of the EU Emissions Trading System (ETS) (OECD 2011; IETA 2015), which is considered the cornerstone of EU's policy to combat climate change (EU 2016).

Another example of the diffusion and power of the concept is the formation of the International Renewable Energy Agency (IRENA). Founded in 2009, IRENA is an official United Nations (UN) observer and has 154 member states, including the European Union (IRENA 2018). IRENA maintains that the benefits of renewable energy are not only climate change mitigation and reduced pollution but also - increasingly - economic growth, employment and energy security (see, e.g. IRENA 2016; IRENA 2017). The existence and status of IRENA illustrate the role of renewable energy as a guiding concept; each form of renewable energy has its own international alliance for industry actors, and these together form the International Renewable Energy Alliance (REN Alliance), yet an intergovernmental agency with states as members was established.

Many businesses have also committed to renewable energy. In 2017, Google stated that it is committed to covering 100 percent of its energy needs with renewable energy (Google 2017). In practice this means purchasing enough wind and solar electricity to account for its electricity consumption (Google 2017). Google justifies this policy both as a means of reducing its carbon footprint and reducing the costs of energy use. Apple reports that it covers its energy needs completely with renewable energy, in practice by producing and purchasing equivalent amounts of wind, solar, hydropower and biofuels in relation to its facilities' consumption (Apple 2018). This $100 \%$ renewables achievement has a major role in the company's environmental reporting. Apple also seeks to increase the share of renewable energy production and procurement of its suppliers (Apple 2018). Facebook is committed to 100 percent "clean and renewable" energy, but measures this according to renewable energy standards (Facebook 2017). These American IT giants are not the only ones fixated with the concept of renewable energy; Facebook and Apple are also members of RE100, a global business initiative of more than 100 large businesses across the world committed to 100 percent renewable electricity (RE100 2018).

Renewable energy is also a prominent concept in academia. A school of thought taking 100 percent renewables as the premise for sustainable energy scenarios has been emerging, led by Jacobson and Deluchi (see, e.g. Jacobson and Deluchi 2011; Deluchi and Jacobson 2011; Plessmann et al. 2014). Such renewables focused studies have evoked several critical responses in energy policy literature (Trainer 2012; Clack et al. 2017; Heard et al. 2017; Heuberger and Dowell 2018) and also generated 
counters to such criticism (e.g. Brown et al. 2018). Common for all streams of the discussion is that they typically conceptualize renewable energy as a distinct part of an energy portfolio.

\section{Problems with the Concept}

As described above, renewable energy is a concept that has been widely adopted across the field of energy policy. It emerged as an alternative to fossil and nuclear energy sources, was later used in conceptualization of an envisioned harmonious society and has now become a central conceptual building block of energy policy theory and practice. It is a clearly defined concept, in the sense that it is widely agreed which sources of energy are renewable and which are not. However, as we show next, the concept as it currently exists might even be harmful to the efforts to combat climate change or power sustainable development.

\subsection{Renewable does not mean sustainable}

Renewable energy is often associated strongly with sustainability. To consider whether renewable energy is sustainable, we first need to define what we understand as sustainability. The original definition by the Brundtland Report in 1987 defined sustainable development as development that meets the needs of the present without compromising the ability of future generations to meet their own needs (United Nations 1987). ${ }^{1}$ Since then, more definitions have followed, typically emphasizing some form of the triple bottom line thinking (see, e.g. Slaper and Hall 2011), where sustainability includes social, environmental and economic domains. Since no energy production comes without some societal and environmental impact, we adopt a pragmatic extension to our definition of sustainability. Sustainable energy enables societal development that is largely, even if not entirely, decoupled from increasing environmental degradation for the foreseeable future.

Among renewables, the sustainability challenges of biomass combustion are perhaps the bestacknowledged. Nevertheless, biomass has an irreplaceable role in many ambitious renewable energy strategies and scenarios published by different organizations (see, e.g. European Commission 2011; Teske et al. 2012; Nordic Energy Research 2016; WWF 2011). Biomass has three major environmental issues and one significant societal issue. First, large scale biofuel production can threaten biodiversity due to the land area and water it needs (Gerbens-Leenes et al. 2009; Erb, Haberl, and Plutzar 2012; Pedroli et al. 2013; Immerzee et al. 2014). Efficient biomass cultivation and harvesting presents a difficult trade-off with conservation of diverse ecosystems in the same area (Erb et al. 2012). Second, energy use of biomass causes considerable net emissions in the short term (Cherubini et al. 2011; Zanchi, Pena, and Bird 2011; Booth 2018), which limits its usefulness in curbing carbon emissions. Third, biomass burning causes particulate pollution that has adverse health and climate impacts (Sigsgaard et al. 2015; Chen et al. 2017). As for societal impacts, on a global scale biomass-based energy production competes with food production for agricultural land and water (Gerbens-Leenes et al. 2009; Dornburg et al. 2010), which could lead to increased food prices, causing major problems for the poorest people and potentially resulting in societal unrest (Bellemare 2014). In general, intensive

$1^{1}$ As an interesting side note, it is worth mentioning that the Brundtland Report defines nuclear fission energy 2 from so-called "fast neutron spectrum" or breeder reactors as renewable energy, because fissile material 3availability effectively ceases to be a concern for their sustainability. It is one indication of how the concept of 4 "renewable energy" has become a political concept for certain sorts of energy systems, that this definition has 5 not been widely accepted. 
agriculture comes with the risk of soil degradation, groundwater pollution and loss of recreational value (Tilman et al. 2002).

Detailed sustainability criteria can help address the abovementioned problems, but such criteria might limit the scalability of biomass considerably. Scalability might not be an issue if the goal is to address local problems. However, for the development and influence of policy with national and global implications and application, we must consider whether or not an energy source can be scaled to provide a substantial fraction of total energy use, and the sustainability implications of this scaling. A biomass solution can be relatively sustainable if used in a local, small-scale manner, but unsustainable in terms of land use, biodiversity loss and carbon emissions if it is used to power entire cities. Finally, the sustainability of biomass use can be modified by technologies such as carbon capture and storage (CCS) combined with bioenergy (BECCS). Proposed BECCS plants would be emission-free, but with a penalty of decreased total energy efficiency. When the energy used for cultivating, harvesting, refining and fuel logistics is taken into account, the energy return on energy invested (EROEI) for BECCS plants, in particular, remains low, possibly even negative (Fajardy and Mac Dowell 2018).

The sustainability issues of renewable energy are not limited to bioenergy. Hydropower can have severe negative environmental impacts, particularly but not exclusively relating to fish populations and similar impacts relating to modification of freshwater hydrology (Chen et al. 2015, Zarfl et al. 2015). Hydropower projects can also release large quantities of greenhouse gases as the original biomass under reservoirs rots, when the water level fluctuation increases and they become large catchment areas of organic matter and nutrients (Deemer et al. 2016) Hydropower projects also often result in displacement of the local populace, and are therefore problematic from a societal sustainability point of view, especially if the negative consequences are faced by poor, indigenous populations while economic benefits are reaped elsewhere (Zarfl et al. 2015).

Geothermal energy has few adverse impacts other than possible local pollution and potentially increasing earthquakes (Moriarty and Honnery 2012), but in order to meet the general definition of renewability it has to be utilized only to the extent the energy flow can replenish itself, which is not always the case (Stefansson 2000; Rybach 2007). The assessed values for global technical potential of geothermal energy vary by orders of magnitude (Moriarty and Honnery 2012), but outside volcanic areas its applications are generally restricted to providing low temperature heating.

The sustainability challenges of wind and solar power are related to the low energy density of the energy flows they are harvesting and their variable nature. Low energy density results in high material and land area requirements (Vidal, Goffe, and Arndt 2013; Brook 2014), and the need to mine high volumes of potentially scarce raw materials such as tellurium and indium for solar photovoltaics (Feltrin and Freundlich 2008; Tao et al. 2011; Grandell and Höök 2015) and rare earths for wind turbines (Alonso et al. 2012; Habib and Wenzel 2014). Variable production of these sources means that in order to provide reliable service, the system as a whole needs some combination of i) major energy storage systems, ii) "overbuild" generation and transmission capacity, or iii) acceptance of decreased level of service. The first two further increase the material and land area requirements to deliver the energy service.

Energy security is a key factor in alleviating poverty (OECD/IEA 2010). From a societal sustainability point of view the distributed nature of wind and solar energy seems positive. In theory they enable local communities to become energy providers, disrupting the power of centralized major power utilities and 
providing a source of local income. Empirical evidence suggests that whether renewable energy plans achieve these aspirations really depends on specific policies. For example, in Germany, the economic benefits of renewable energy policies have not been felt by the less affluent but rather by those with considerable disposable income and opportunities to invest in and operate decentralized power production (Stefes 2016).

None of the above arguments mean that renewable energy technologies cannot be providers of sustainable energy. As with any form of energy production, the energy sources labeled as renewable come with pros and cons that depend on their scale and their role in the energy system.

\subsection{Renewables are very different from each other}

Another problem with the concept of renewable energy is that it is an umbrella construct that includes very different types of energy sources. The energy densities, practical siting requirements and physical processes of different forms of renewable energy vary greatly.

Table 1 illustrates the miscellaneous nature of renewable energy sources. The different renewables are compared based on their power density, primary form of energy harvested, land use, capacity and nature of fluctuation. Power density is here measured by estimated land use intensity. This number depends greatly on the underlying assumptions of what is included, but the diverse nature of the renewables itself makes direct comparison complicated.

As Table 1 shows, the renewable forms of energy differ from each other in almost all aspects. One thing is common, however; all these energy sources have a relatively low power density per area (for comparison, these are around 0.2 and 0.1 for coal and nuclear energy, respectively; Fritsche et al. 2017), although there is an order of magnitude difference in this aspect too. Different renewables harvest different forms of energy, which then requires different processes to convert the energy into useful electricity or heat. Finally, it should be noted that most of these renewables are not able to directly produce the high temperatures required by many industrial processes (Naegler et al. 2015).

The variability of energy production is a well-known challenge of many forms of renewable energy. All these sources except biomass are dependent on local conditions, resulting in some form of variability. However, the time scales and predictability of this variability are very different from each other. Wind and solar power are directly dependent on the ambient weather conditions, causing the power production to fluctuate in a matter of seconds (Anvari et al. 2016). Availability of hydropower depends on water levels and flows on time scales varying from hourly and daily fluctuation of run-ofriver power plants to seasonal and annual fluctuation of storage hydropower with large reservoirs (Kumar et al. 2011; Gaudard and Romerio 2014). It should be noted that technological innovations can alter the figures of Table 1 in future. The fundamental physical limitations such as solar insolation, wind catchment or biological primary production per unit of area however persist, limiting major shifts in the power density or the nature of variability.

Table 1: The varying nature of different renewable energy forms. Coal and nuclear energy included for comparison. 


\begin{tabular}{|c|c|c|c|c|}
\hline Energy source & $\begin{array}{l}\text { Primary form of } \\
\text { energy }\end{array}$ & $\begin{array}{l}\text { Land use intensity }{ }^{\mathrm{a}} \\
{\left[\mathrm{m}^{2} / \mathbf{M W h}\right]}\end{array}$ & $\begin{array}{l}\text { Capacity } \\
\text { factor }^{d}\end{array}$ & Power fluctuation \\
\hline $\begin{array}{l}\text { Solar } \\
\text { photovoltaic } \\
\text { panels }\end{array}$ & $\begin{array}{l}\text { Electricity by } \\
\text { photovoltaic effect }\end{array}$ & 10 & $16-30 \%$ & $\begin{array}{l}\text { Directly weather dependent. In } \\
\text { northern latitudes, season } \\
\text { dependent as well. }\end{array}$ \\
\hline $\begin{array}{l}\text { Concentrated } \\
\text { solar power }\end{array}$ & Thermal energy & 15 & $25-80 \%$ & $\begin{array}{l}\text { Directly weather dependent, } \\
\text { unless backed by heat storage. }\end{array}$ \\
\hline Hydropower & Kinetic energy & 10 & $12-62 \%$ & $\begin{array}{l}\text { Dependent on seasonal } \\
\text { precipitation and accumulating } \\
\text { sedimentation }\end{array}$ \\
\hline Wind power & Kinetic energy & 1 & $26-52 \%$ & $\begin{array}{l}\text { Directly weather dependent, } \\
\text { with some seasonal dependency. }\end{array}$ \\
\hline Biomass & Chemical energy & $500^{\mathrm{b}}$ & $70-90 \%$ & Dependent on fuel properties. \\
\hline Geothermal & Thermal energy & 2.5 & $72-98 \%$ & $\begin{array}{l}\text { Dependent of local rate of } \\
\text { depletion. }\end{array}$ \\
\hline Wave power & Kinetic energy & $4.6^{c}$ & $26 \%$ & $\begin{array}{l}\text { Directly weather and tide } \\
\text { dependent. }\end{array}$ \\
\hline \multicolumn{5}{|c|}{ Coal and nuclear figures presented for comparison } \\
\hline Coal & Chemical energy & $\begin{array}{l}0.2 \text { (underground) } \\
5 \text { (open-cast) }\end{array}$ & $75-93 \%$ & Fully controllable. \\
\hline Nuclear & Nuclear fission & 0.1 & $85-90 \%$ & $\begin{array}{l}\text { Dependent on fuel and plant } \\
\text { properties. }\end{array}$ \\
\hline
\end{tabular}

${ }^{a}$ Refers to the land area required for production of one megawatt hour of energy, according to the "typical" values by Fritsche et al. (2017). Such figures should always be considered indicative only, since their exact values are highly dependent on the background assumptions of the calculations. However, they clearly illustrate the differing scales of energy intensity.

${ }^{b}$ Figure for crop-based biomass.

${ }^{c}$ Tidal wave power is still largely under development. This figure is based on estimates presented by Waters (2008). 
${ }^{d}$ Capacity factor is the ratio between average power and peak capacity. Presented figures are for utility scale technologies and based on Transparent Cost Database (2018).

The incoherence of a concept is not necessarily a problem. There are many ambiguous concepts that still have significant explanatory power and practical use. However, in energy policy design and discourse, such incoherence can cause confusion. Businesses, cities, states and countries are making pledges to run on $100 \%$ renewable energy or electricity and these pledges are compared to each other, yet they describe very different energy systems in terms of infrastructure, material flows and societal, environmental and economic impact. For example, the fact that Iceland, Norway and Costa Rica have abundant hydropower or geothermal resources and can produce practically all their electricity from renewable sources tells us very little about the policy options in countries that are not as well endowed. Nevertheless, it is common to see these countries used as examples of successful renewable energy policies, and even academic publications often use these examples to make the case for $100 \%$ renewable energy (e.g. Brown et al. 2018).

\subsection{Results of policies based on renewable energy are mixed}

Conceptualizing certain forms of energy as renewable could be justified, if it leads to favorable policy outcomes. What 'favorable' exactly means depends, of course, on goals set for the policy. The Paris agreement (United Nations 2016) dictates in general that signatory countries should aim at sufficient emission reductions to limit global warming to well below $2^{\circ} \mathrm{C}$ above pre-industrial levels. At the same time, countries are interested in maintaining a secure supply of energy and improving their economic performance and competitiveness.

The World Energy Council ranks energy policy achievement according to the so-called 'Energy Trilemma': the ability to provide energy through three dimensions of energy security, energy equity and environmental sustainability (World Energy Council 2017). The effectiveness of policy in meeting the Energy Trilemma is one illustrative way to systematically assess and rank energy policies. Figure 3 illustrates the energy trilemma rankings and share of renewables in total primary energy supply for 120 countries for which data was available for year 2017. As we can see, there is low correlation between a high share of renewables and "good" energy policy - and in fact the observable correlation is mostly negative. There are high ranking countries with a low share of renewables and there are low ranking countries with a very high share of renewables. Naturally, the renewables in question are very different. In the countries with poorer performance, the renewables are often manually collected firewood and manure. Again, the label 'renewable' tells very little about the exact type of energy used. 


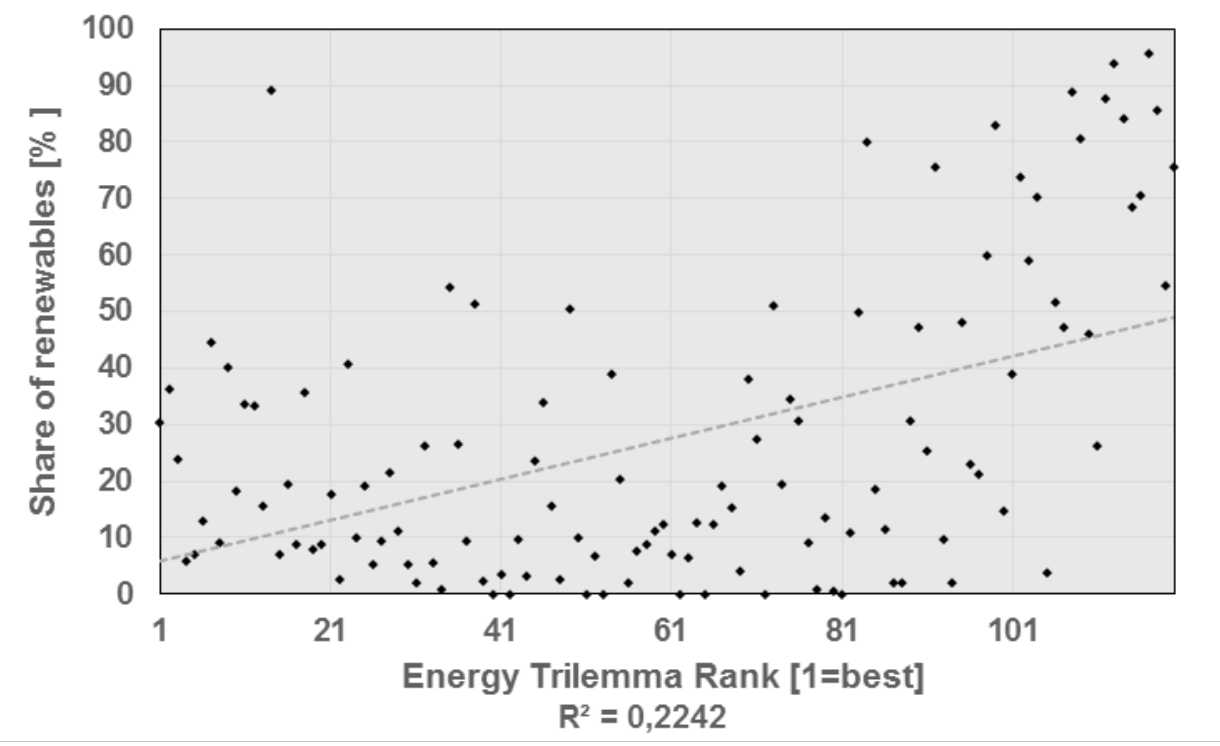

Figure 3: The Energy Trilemma rankings and share of renewables in total primary energy supply in 2017 for 120 countries (Data: World Energy Council 2017)

Perhaps the best-known renewable-based national energy policy is the Energiewende of Germany, which aims to supply 60 percent of final energy consumption from renewables by 2050, along with pledges of emission reductions in line with EU policy and a complete nuclear phase-out by 2022 (Agora Energiewende 2017). The premise of Energiewende has a long history in Germany, and the current set policies were decided in 2010 and 2011 (Agora Energiewende 2017; Beveridge and Kern 2013). By 2017, German $\mathrm{CO}_{2}$ emissions had dropped by 4 percent compared to 2010 (Umweltbundesamt 2018), and in 2018 the newly elected German government announced that the country would not meet the emission reduction targets it had set for 2020 (Oroschakoff 2018). Although it is difficult to say what the emissions would have been without the Energiewende, these challenges were expected. Several studies have pointed out that the policy may result in challenges in grid management and reducing $\mathrm{CO}_{2}$ intensity (Bruninx et al. 2013; Schroeder et al. 2013; Knopf et al. 2015; Sopher 2015). The electricity prices for households are the second highest among all EU member countries (Eurostat 2017). Yet at the same time, the economic growth of Germany has on average been higher than in the EU or Euro area in general (European Commission 2018; Eurostat 2018b), with Matthes et al. (2015) arguing that Germany's energy policy has had an important role in lowering the price of wind and solar generation worldwide, potentially playing a beneficial role in reducing greenhouse emissions beyond German political borders. Thus, depending on what is valued and how, the Energiewende might be judged either a success or a failure. However, in terms of reducing Germany's domestic greenhouse gas emissions and ensuring affordability for German consumers, it has not been effective.

While energy security and equity are important, the case can be made that curbing carbon emissions is the global priority of energy policy at the moment. So, in a world where renewable energy is frequently framed as a key solution to climate change, how have we fared in reducing emissions? The answer is, quite poorly. After remaining flat for three years (IEA 2017b), global $\mathrm{CO}_{2}$ emissions are estimated to have grown by 2 percent in 2017 (Global Carbon Project 2018). Even staying below the $2^{\circ} \mathrm{C}$ threshold 
without a high likelihood of overshooting would require major annual reductions. The national pledges set for the Paris agreement are not nearly enough (Sanderson, O'Neill, and Tebaldi 2016), and there is still a wide gap between those pledges and actual policies (Victor et al. 2017). Naturally, the current conceptualization of energy as renewable or not can't be adjudged as the root cause of failed climate policies. But our conceptualizations have coexisted with this failure, and we suspect that this has limited our policy choices.

\subsection{Renewable energy enables bait-and-switch tactics}

Despite the controversies described above, the concept of renewable energy has become ingrained in climate policy logic. Climate policy can be seen as a complex, issue-based field (Schüssler et al. 2014), where the activities of the many actors involved are no longer connected to the central institutions or their goals. This can be the result of goal grafting (Grodal and O'Mahony 2017), where a shared goal exists, while potentially disparate underlying interests - such as promoting certain forms of energy production - are preserved. Such goal grafting allows actors participating in the field to rhetorically support the shared grand goal without actually abandoning their underlying interests (Grodal and $\mathrm{O}$ 'Mahony 2017).

In the context of energy policy, the loose 1970s-era definition of "renewable energy" and its positive associations have permitted politicians and lobbyists to get away with what are essentially bait-andswitch schemes that seem to address climate change, but in reality serve only to improve public image or promote selected technologies or interest groups and may hinder emission reductions or even increase them and cause other undesirable environmental impacts.

As we described in section 4.1, bioenergy is perhaps the most problematic of all energy sources that are nevertheless widely considered renewable. Despite its problems, the major upside of bioenergy from a domestic political viewpoint is that it is argued to provide opportunities for domestic businesses or to bring benefits to rural areas (see, e.g. BioPAD 2013; BioenNW 2015) which face the challenges of growing urbanization and a lack of economic opportunity. The umbrella of renewable energy enables downplaying this tradeoff of potential benefits for problems while including increased bioenergy use in plans or policies that are labeled climate friendly and progressive. A recent example is the planned national coal ban in Finland, which is communicated as determined and accelerated action for climate change mitigation and promotion of renewable energy (Ministry of Economic Affairs and Employment of Finland 2018), but which in reality is projected even in the official reports as relying mostly on biomass for replacing coal and doesn't result in direct emission reductions on a European level since it affects only emissions already controlled within the ETS (Pöyry Management Consulting 2018). City scale examples are the climate plans of Copenhagen (City of Copenhagen 2012) and Stockholm (City of Stockholm 2016) and the renewable energy strategy of Vancouver (City of Vancouver 2015). Each of these plans frames the city in question as a forerunner in climate change mitigation and emphasizes the increase in the use of renewable energy. All the plans, however, relies heavily on bioenergy, especially in heating and transportation.

The concept of renewable energy also enables biased visual communication of energy policies. Based on our experiences, the typical illustration of a news piece, press release or publication about renewable energy shows pictures of wind turbines or solar panels, whereas illustrations of biomass combustion are rare even if in a particular case a significant percentage of the energy generated would come from 
biomass (see, e.g. WWF 2011; City of Copenhagen 2012; European Parliament 2018; City of Stockholm 2016; Federal Ministry for Sustainability and Tourism of Austria 2018). A brief search among three major stock photography services reflects this bias as well: ${ }^{2}$ Of the 300 popular photos on renewable energy we browsed, only 15 depicted bioenergy, with the photos being dominated by wind turbines and solar panels.

Another worrisome development is the interest of the fossil fuel industry in using the concept of renewable energy to promote increased use of natural gas. Examples include the Norwegian energy company Statoil (Equinor since 2018) running an international advertisement that labeled natural gas as a natural partner for renewables, ${ }^{3}$ the Interstate Natural Gas Association of America framing natural gas as the ideal resource to complement renewables and as an ally of renewable energy (INGAA 2016), and the Finnish gas and diesel generator manufacturer Wärtsilä promoting a fully renewable future without a schedule (Wärtsilä 2018). The Corporate Europe Observatory, a non-profit organization focused on following lobbying activities within the EU, has reported systematic efforts of the fossil fuel industry lobby to utilize the positive views on renewable energy to promote policies supporting natural gas (Blanyà and Sabido 2017). This again shows how the vague concept of renewables enables such bait-and-switch tactics that move policy ever further away from the underlying issue of greenhouse emissions.

It appears that the vendors of fossil gas and related technologies regard the intermittency of most renewable energy sources as a business opportunity, one that will maintain the relevance of their product in the face of policies that are, in theory, supposed to work against their product. Although in a technical sense gas is indeed a good partner to variable renewables, gas is still a significant source of greenhouse gas emissions; not just when burned to carbon dioxide, but also when methane inevitably leaks from wellheads and pipelines (Howarth 2014; Schwietzke et al. 2016). There is reason to fear that the co-promotion of gas and renewables will result in a lock-in to an energy system that includes a significant share of renewable energy, but will not achieve more ambitious climate targets because cheap fossil gas makes investments in non-fossil alternatives less appealing.

Assessing the efficacy and broader impact of these bait-and-switch tactics would require more detailed research. It seems clear, however, that the ambiguity and positive connotations of the concept of renewable energy have at least partly enabled these tactics.

\subsection{There is no renewable energy}

\footnotetext{
$6^{2}$ The search included the online stock photo services by Getty Images, Adobe Stock and iStock. For each a search with term 7"renewable energy" was conducted and sorted by popularity. The first 100 photos were assessed. Photos of pellets, 8 combustion, energy crops or timber were counted, whereas photos of trees, plants or nature in general were not included in 9the count. The search was conducted on 19.11.2018.

$10^{3}$ See Twitter posts with photo evidence:

11Rytky, Tiina (@TiinaRytky) "Natural Gas. The Perfect Partner for Renewables. \#irony \#diablocanyon \#climate” 30.7.2016. 12Tweet. [URL: https://twitter.com/TiinaRytky/status/759319625406480384]

13Hellesen, Carl (@hellesen_) “And I think the green cred gas/oil companies get by cheering for renewables is a big part of 14the problem.”18.7.2017. Tweet. [URL: https://witter.com/hellesen_/status/887241940848320512]

15Riley, Brook (@pzbrookriley) "Statoil ads at Brussels airport. They really are determined to make us think \#gas isn't a 16\#fossilfuel!” 5.1.2016 [URL: https://twitter.com/pzbrookriley/status/684450608309530625]

17
} 
Finally, as a term, renewable energy is an oxymoron of sorts. Conservation of mass-energy guarantees that energy never disappears, but the second law of thermodynamics dictates that the total entropy in an isolated system can never decrease. Energy can be transformed in different processes, but the total exergy - the available, useful work - decreases irreversibly. Energy itself cannot in the strict sense be renewed.

This of course may be nitpicking; what renewability in energy means is that the production harvests some form of energy or material flow that is renewed by planetary or stellar processes faster than it is depleted by its use. Still, renewability is an issue that should not be taken for granted. At least with current technologies, all forms of renewable energy production rely on machines built with nonrenewable minerals. If variable energy production is balanced by chemical batteries, it emphasizes this problem even more. Bioenergy relies on renewed biomass flows. While the biomass volume can be renewed, the loss of biodiversity caused by land use changes is irreversible. Hydropower has similar tradeoff issues.

It is also worth noting that non-renewability is not the primary concern for any form of energy now in widespread use. Naturally, depletion becomes an issue in the long run, but the primary reason driving the need to reduce the use of fossil fuels drastically is the climate change the greenhouse gas emissions are causing.

\section{Discussion and Alternative Conceptualizations}

As we point out, there are many problems with the concept of renewable energy. While often associated with sustainability, the two concepts can also be completely conflicting. The concept of renewability in energy is fundamentally incoherent, encompassing as it does very different forms of energy production. Share of renewable energy is a poor indicator for successful energy policy. The concept of renewable energy also enables goal grafting that can drive environmental considerations to the margins of energy policy. Finally, strictly speaking, renewable energy does not even exist.

There are good grounds to claim that the concept is not only problematic but even harmful. How could the forms of energy production then be more usefully conceptualized for better supporting the development of policy to effectively combat climate change and provide energy for sustainable development? Sustainable energy would be a logical way of conceptualizing, but the term has already been adopted by some to describe selected types of renewable energy and energy efficiency (see, e.g. Prindle et al. 2007; Conserve Energy Future 2018). Other framings exist also; for example, Siemens states that a sustainable energy supply is based both on renewable and conventional energy (Siemens 2018).

Problems with certain forms of renewable energy have led to reframing of selected renewables as " $n e w$ renewables" (Jordan-Korte 2011, 14) that excludes hydro and traditional biomass or as "WWS" that stands for wind, water and sunlight (Jacobson et al. 2017). However, there is reason to believe that the distinction is not clear to the public and politicians at large, and that WWS studies are commonly conceptualized as promoting renewable energy in general, not specifically "new" renewables or WWS. Global energy scenarios that rely on WWS alone are also unlikely to provide enough energy for equitable and sustainable economic development (Trainer et al. 2012), resulting in the problem of how to frame and conceptualize all the forms of energy outside these three sources. The U.S. Department of 
Energy's concept of "clean energy" (Department of Energy 2018) is broader and includes basically all energy sources other than fossil fuels. Cleanliness is, however, a problematic term in the sense that all forms of energy production have an environmental impact even if their lifecycle carbon dioxide emissions are low. "Clean" can therefore be deployed as a relative term in the energy policy discourse. Natural gas is cleaner than coal both in terms of $\mathrm{CO}_{2}$ and other emissions, and then there is also the contradictory lobbyist idea of "clean coal" (Pearce 2008).

A more useful concept can be low-carbon energy, but it opens up the debate about the problematic categorization of biomass, which may be carbon neutral on a long enough (often decadal) timescale if new growth absorbs enough carbon dioxide, but at least technically is not low-carbon (since it consists largely of carbon) (e.g. Kallio et al. 2013). The timescale matters, because effective climate change mitigation should reduce the amount of carbon ending up in the atmosphere now, not just decades hence. Finally, from an engineering perspective, energy sources could be categorized based on the nature of the production process. In mitigating climate and health impacts, the division between combustion-based and non-combustion based energy production might be the most suitable.

Given the realities of climate change, we suggest a quadrant for making sense of the energy options available (Table 2). It provides a simple yet accurate division between different energy sources, and a roadmap that probably ought to be followed by the whole of human civilization: away from the combustion-based energy sources in quadrants 4 and 2, and towards combustion free, low-carbon sources in quadrant 1, all the while avoiding quadrant 3's siren song of mostly combustion free yet high-carbon combination of renewables and fossil fuels. Other conceptualizations are possible, but for the duration of the climate emergency, it seems useful to focus on those aspects of energy sources that are most pertinent for avoiding dangerous climate change.

Besides non-combustion based renewable energy, we have included nuclear power in quadrant 1 as a low-carbon energy source due to its low direct and indirect $\mathrm{CO}_{2}$ emissions (Warner and Heath 2012). While nuclear power is often considered controversial (Ho et al. 2018) and faces serious opposition and reluctance in many countries (Kim et al. 2014), it has a key role in many mitigation pathways presented in the Special Report on Global Warming of $1.5^{\circ} \mathrm{C}$ (IPCC 2018) and the earlier Fifth Assessment Report (Bruckner et al. 2014) by the Intergovernmental Panel on Climate Change. Public opinion should not be dismissed as insignificant, and nuclear waste, nuclear accidents and proliferation of nuclear weapons are indisputably significant challenges that require attention and proper control and already limit the applicability of nuclear power. Nevertheless, at least in historical experience, per energy unit produced, the impact of nuclear energy on health (Hirschberg et al. 2016), land use (Cheng and Hammond 2017) and biodiversity (Brook and Bradshaw 2014) has remained relatively modest.

Table 2. Carbon-combustion quadrant.

\begin{tabular}{|l|l|l|}
\hline $\begin{array}{l}\text { Too much } \\
\text { carbon }\end{array}$ & $\begin{array}{l}\text { 3. Energy systems that have nominally high shares of low carbon } \\
\text { generation but are backed up by high carbon fuels such as fossil } \\
\text { methane or large-scale biomass }\end{array}$ & $\begin{array}{l}\text { 4. Fossil fuels, biomass } \\
\text { (non-optimal sources, short- } \\
\text { term) }\end{array}$ \\
\hline
\end{tabular}




\begin{tabular}{|l|l|l|}
\hline $\begin{array}{l}\text { Low } \\
\text { carbon }\end{array}$ & $\begin{array}{l}\text { 1. Solar, wind, hydro, wave, tidal, geothermal, nuclear and } \\
\text { energy systems based on these + low-carbon energy storage } \\
\text { methods }\end{array}$ & $\begin{array}{l}\text { 2. Biomass (selected } \\
\text { sources, long-term) }\end{array}$ \\
\hline & Mostly combustion free & Mostly combustion based \\
\hline
\end{tabular}

We should also discuss the question of whether the focus of energy policy and debate should be shifted completely away from categorizing different ways of producing energy and agonizing over which ones to support and which to oppose. As discussed in sections 4.1 and 4.2, energy sources and geographic conditions vary radically, and with the current conceptualization of energy sources as "good" and "bad", comparison between apples and oranges becomes inevitable. One beneficial way to reframe the discussion could be to shift the focus from conceptualizing energy systems through energy production methods - which also lets other sectors off the hook, so to speak - to conceptualizing sustainable, lowcarbon societies and what they might look like in reality. The concept of deep decarbonization (see, e.g. Bataille et al. 2016) could be a fruitful future path. All in all, we consider it important to critically evaluate the current frames and framing processes and their impact within the field of energy policy.

\section{Conclusion and Policy Implications}

Framing and prevalent frames in the field of energy policy have a major role in forming policies, as policy options are limited by the institutional conceptualizations and discourse available. Renewable energy has become a dominant concept within energy policy, and many national and international legal frameworks and policies are specifically designed around the idea of categorizing energy sources as renewable or non-renewable. In public discourse, renewable energy is framed in a way that strongly associates it with sustainability and successful climate change mitigation. However, as we point out, the whole concept of renewable energy is questionable.

An incoherent and misleading concept is a problematic basis for policy development. We therefore suggest that it would be best to avoid renewable energy as a term altogether and instead to conceptualize energy sources based on their carbon emissions and whether they are based on combustion or not. It might seem somewhat futile to try to dramatically transform discourse so deeply ingrained within a field. Still, we must acknowledge the collective global failure in mitigating climate change and the institutionalized concepts that seem to have played a role in that failure.

More nuanced terminology may in itself not be a panacea nor the key to effective climate mitigation. It can, however, be a step in the right direction. The next steps should include, inter alia, more detailed empirical analysis and quantification of the costs and benefits of various truly low-carbon approaches. With this paper, we call upon the research community to develop and, perhaps most importantly, use in their outreach and communications more accurate concepts and descriptions to measure and communicate the desired policies and end-states, instead of relying on old concepts which, while widely used in common parlance, are increasingly removed from the reality. We are also calling for more attention to be paid to the "bait and switch" tactics used by politicians and industry lobbyists to sell questionable energy sources as "renewable", and to the fossil fuel firms using renewables- 
compatibility as a marketing tool. We urgently need energy policies that are focused on emissions rather than problematic and tendentious renewability. Therefore, let our words help, not limit our efforts to save the world.

\section{References}

Alonso, E., Sherman, A.M., Wallington, T.J., Everson, M.P., Field, F.R., Roth, R., Kirchain, R.E. (2012) Evaluating rare earth element availability: a case with revolutionary demand from clean technologies, Environmental Science \& Technology, vol. 46, iss. 6, pp. 3406-3413. https://doi.org/10.1021/es203518d

Agora Energiewende (2017) The Energiewende in a nutshell - 10 Q \& A on the German energy transition. [URL:https://www.agora-energiewende.de/fileadmin/Projekte/2017/Energiewende_in_a_nutshell/ Agora_The Energiewende in_a nutshell_WEB.pdf] Accessed 29.8.2018.

Ansari, S., Gray, B., Wijen, F. (2011) Fiddling while the ice melts? How organizational scholars can take a more active role in the climate change debate, Strategic Organization, vol. 9, iss.1, pp. 70-76. https://dx.doi.org/10.1177/1476127010395525

Anvari, M, Lohmann, G., Wächter, M., Milan, P., Lorenz, E., Heinemann, D., Reza Rahimi Tabar, M., Peinke, J. (2016) Short term fluctuations of wind and solar power systems, New Journal of Physics, vol. 18, June 2016. https://dx.doi.org/10.1088/1367-2630/18/6/063027

Apple (2018) Environmental Responsibility Report 2018 Progress Report, Covering Fiscal Year 2017. [URL:

https://www.apple.com/environment/pdf/Apple_Environmental_Responsibility_Report_2018.pdf] Accessed 16.8.2018

Blanyá, S., Sabido, P. (2017) The Great Gas Lock-in - Industry lobbying behind the EU push for new gas infrastructure, Corporate Europe Observatory. [URL: https://corporateeurope.org/sites/default/files/ the_great_gas_lock_in_english_.pdf] Accessed 19.11.2018

Bataille, C., Waisman, H., Colombier, M., Segafredo, L., Williams, J., Jotzo, F. (2016) The need for national deep decarbonization pathways for effective climate policy, Climate Policy, vol. 16. iss. Sup1, pp. s7-s26. https://doi.org/10.1080/14693062.2016.1173005

Bell, L. (1906). The Utilization of Natural Energy. Cassier's Magazine, Vol. 29, pp. 466-476.

Bellemare, M.F. (2014) Rising Food Prices, Food Price Volatility, and Social Unrest, American Journal of Agricultural Economics, vol. 97, iss. 1, pp. 1-21. https://doi.org/10.1093/ajae/aau038

Benford, R.D., Snow, D.A. (2000) Framing Processes and Social Movements: An Overview and Assessment, Annual Review of Sociology, vol. 26, pp.611-639. https://www.jstor.org/stable/223459 
Beveridge, R., Kern, K. (2013). The Energiewende in Germany: background, developments and future challenges. Renewable Energy Law and Policy Review, vol. 4, no. 1, pp. 3-12.

http://www.jstor.org/stable/24324649

BioenNW (2015) Benefits of Bioenergy, Project web site. [URL: https://bioenergy-nw.eu/the-benefitsof-bioenergy/] Accessed 24.8.2018.

BioPAD (2013) Benefits of bioenergy, Project web site. [URL: https:/www.biopad.eu/aboutbioenergy/benefits-of-bioenergy/] Accessed 24.8.2018.

Booth, M.S. (2018) Not carbon neutral: Assessing the net emissions impact of residues burned for bioenergy, Environmental Research Letters, vol. 13, no. 3, pp. 1-10.https://doi.org/10.1088/1748-9326/ aaac88

Brook, B.W., Bradshaw, C.J. (2014) Key role for nuclear energy in global biodiversity conservation, Conservation Biology, vol. 29, iss. 3, pp. 702-712. https://doi.org/10.1111/cobi.12433

Bruckner T., I.A. Bashmakov, Y. Mulugetta, H. Chum, A. de la Vega Navarro, J. Edmonds, A. Faaij, B. Fungtammasan, A. Garg, E. Hertwich, D. Honnery, D. Infield, M. Kainuma, S. Khennas, S. Kim, H.B. Nimir, K. Riahi, N. Strachan, R. Wiser, and X. Zhang, (2014) Energy Systems. In: Climate Change 2014: Mitigation of Climate Change. Contribution of Working Group III to the Fifth Assessment Report of the Intergovernmental Panel on Climate Change [Edenhofer, O., R. Pichs-Madruga, Y. Sokona, E.

Farahani, S. Kadner, K. Seyboth, A. Adler, I. Baum, S. Brunner, P. Eickemeier, B. Kriemann, J. Savolainen, S. Schlömer, C. von Stechow, T. Zwickel and J.C. Minx (eds.)]. Cambridge University Press, Cambridge, United Kingdom and New York, NY, USA

Bruninx, K., Madzharov, D., Delarue, E. \& D'haeseeler, W. (2013) Impact of the German nuclear phase-out on Europe's electricity generation-A comprehensive study, Energy Policy, vol. 60, pp. 251261. https://doi.org/10.1016/j.enpol.2013.05.026

Brown, T. W., Bischof-Niemz, T., Blok, K., Breyer, C., Lund, H., Mathiesen, B. V. (2018). Response to 'Burden of proof: A comprehensive review of the feasibility of $100 \%$ renewable-electricity systems.', Renewable and Sustainable Energy Reviews, vol. 92, pp. 834-847. https://doi.org/10.1016/j.rser.2018.04.113

Caprotti, F. (2012) The cultural economy of cleantech: environmental discourse and the emergence of a new technology sector, Transactions of the Institute of British Geographers, vol. 37, iss. 3, pp. 370-395. https://doi.org/10.1111/j.1475-5661.2011.00485.x

Chen, S., Chen, B., Fath, B.D. (2015) Assessing the cumulative environmental impact of hydropower construction on river systems based on energy network model, Renewable and Sustainable Energy Reviews, vol. 42, pp. 78-92. https://doi.org/10.1016/j.rser.2014.10.017

Chen, J., Li, C., Ristovski, Z., Milic, A., Gu, Y., Islam, M.S., Wang, S. Hao J., Hao, J., Zhang, H., He, C., Guo, H., Hongbo, F., Miljevic, B., Morawska., L., Thai, P., Lam, Y.F., Pereira, G., Ding, A., huang, X., Dumka, U.C. (2017) A review of biomass burning: Emissions and impacts on air quality, health and 
climate in China, Science of The Total Environment, vol. 579, pp. 1000-1034. https://doi.org/10.1016/j.scitotenv.2016.11.025

Cheng, V.K.M., Hammond, G.P. (2017) Life-cycle energy densities and land-take requirements of various power generators: A UK perspective, Journal of the Energy Institute, vol. 90, iss. 2, pp. 201213. https://doi.org/10.1016/j.joei.2016.02.003

Cherubini, F., Peters, G.P., Berntsen, T., Stromman, A.H., Hertwich., E. (2011) $\mathrm{CO}_{2}$ emissions from biomass combustion for bioenergy: atmospheric decay and contribution to global warming, GCB Bioenergy, vol. 3, iss. 5, pp. 413-426. https://doi.org/10.1111/j.1757-1707.2011.01102.x

City of Copenhagen (2012) CPH 2025 Climate Plan - A Green, Smart and Carbon Neutral City, The City of Copenhagen Technical and Environmental Administration, Edition Sept 2012. [URL: https://international.kk.dk/artikel/carbon-neutral-capital] Accessed 17.11.2018

City of Stockholm (2016) Strategy for a fossil-fuel free Stockholm by 2040, City Executive Office, December 2016, Ref. no. 134-175/2015. [URL:

https://international.stockholm.se/globalassets/rapporter/strategy-for-a-fossil-fuel-free-stockholm-by2040.pdf] Accessed 17.11.2018

City of Vancouver (2015) Renewable City Strategy 2015-2050. [URL:

https://vancouver.ca/files/cov/renewable-city-strategy-booklet-2015.pdf] Accessed 17.11.2018

Clack, C.T. M., Qvist, S.A., Morgan Bazilian, J.A., Brandt, A.R., Caldeira, K., Davis, S.J., Diakov, V., Handschy, M.A., Hines, P.D.H., Jaramillo, P., Kammen, D.M., Long, J.C.S., Morgan, M.G., Reed, A., Sivaram, V., Sweeney, J., Tynan, G.R., Victor, D.G., Weyant, J.P., Whitacre, J.F. (2017) Evaluation of a proposal for reliable low-cost grid power with $100 \%$ wind, water, and solar, PNAS, vol. 114, iss. 26, pp.6722-6727. https://doi.org/10.1073/pnas.1610381114

Clarke, F. W., Wiley, H. W., Herty, C. H., Parr, S. W., Dole, R. B. (1909). Report of the Committee of the American Chemical Society Appointed to Cooperate with the National Conservation Commission. Science, 29(745), pp. 570-574. https://doi.org/10.1126/science.29.745.570

Conserve Energy Future (2018) What is Sustainable Energy?, Web site. [URL: https://www.conserveenergy-future.com/sustainableenergy.php] Accessed 29.3.2018.

Cotton, M., Rattle, I., Van Alstine, J. (2014) Shale gas policy in the United Kingdom: An argumentative discourse analysis, Energy Policy, vol. 73, pp. 427-438. https://doi.org/10.1016/j.enpol.2014.05.031

Dahlsrud, A. (2006) How corporate social responsibility is defined: an analysis of 37 definitions, Corporate Social Responsibility and Environmental Management, vol.15, iss. 1, pp. 1-13. https://doi.org/10.1002/csr.132

Deemer, B.R., Harrison, J.A., Li, S., Beaulieu, J.J., DelSontro, T., Barros, N., Bezerra-Neto, J.F., Powers, S.M., dos Santos, M., Vonk, J.A. (2016) Greenhouse Gas Emissions from Reservoir Water 
Surfaces: A New Global Synthesis, BioScience, vol. 66, iss. 11, pp. 949-964. https://doi.org/10.1093/biosci/biw117

Delucchi, M.A., Jacobson, M.Z. (2011) Providing all global energy with wind, water, and solar power, Part II: Reliability, system and transmission costs, and policies, Energy Policy, vol. 39, iss. 3, pp. 11701190. https://doi.org/10.1016/j.enpol.2010.11.045

Department of Energy (2018) Clean Energy, web site [URL: https:/www.energy.gov/scienceinnovation/clean-energy] Accessed 29.3.2018

DiMaggio, P., Powell, W.W. (1983) The iron cage revisited: institutional isomorphism and collective rationality in organizational fields, American Sociological Review, Vol. 48, Iss. 2, pp. 147-160. http:// dx.doi.org/10.2307/2095101.

Dornburg, V., van Vuuren, D., van de Ven, G., Langeveld, H., Meeusen, M., Banse, M., van Oorschot, M., Ros, J., van den Born, G., Aiking, H., Londo, M., Mozaffarian, H., Verweij, P., Lysen, E., Faaij, A. (2010) Bioenergy revisited: Key factors in global potentials of bioenergy, Energy \& Environmental Science, Vol. 3., pp. 258-267. https://doi.org/10.1039/B922422J

Erb, K-H., Haberl, H., Plutzar, C. (2012) Dependency of global primary bioenergy crop potentials in 2050 on food systems, yields, biodiversity conservation and political stability, Energy Policy, vol. 47, August 2012, pp. 260-269. https://doi.org/10.1016/j.enpol.2012.04.066

EU (2009) Directive 2009/28/EC Of the European Parliament and of the Council of 23 April 2009 on the promotion of the use of energy from renewable sources and amending and subsequently repealing Directives 2001/77/EC and 2003/30/EC.

EU (2016) The EU Emissions Trading System (EU ETS) Factsheet. [URL:

https://ec.europa.eu/clima/sites/clima/files/factsheet_ets_en.pdf] Accessed 16.11.2018.

EU (2018) Renewable energy directive, European Union information website. [URL:

https://ec.europa.eu/energy/en/topics/renewable-energy/renewable-energy-directive] Accessed 30.8.2018.

European Commission (2011) Energy Roadmap 2050, Communication from the commission to the European Parliament, the Council, the European Economic and Social Committee and the Committee of the Regions. Brussels, 15.12.2011. [URL: http://eur-lex.europa.eu/legal-content/EN/TXT/PDF/? uri=CELEX:52011DC0885\&from=EN] Accessed 30.8.2018.

European Commission (2018) Economic forecast for Germany, Spring 2018, produced by the Directorate-General for Economic and Financial Affairs (DG ECFIN). [URL: https://ec.europa.eu/info/ business-economy-euro/economic-performance-and-forecasts/economic-performance-country/ germany/economic-forecast-germany en] Accessed 30.8.2018.

European Parliament (2018) Energy: new ambitious targets on renewables and energy efficiency, Press release 13.11.2018. [URL: http://www.europarl.europa.eu/news/en/press-room/20181106IPR18315/ energy-new-ambitious-targets-on-renewables-and-energy-efficiency] Accessed 19.11.2018 
Eurostat (2017) Electricity price statistics, Eurostat Statistics Explained. Web resource. [URL: http://ec.europa.eu/eurostat/statistics-explained/index.php/Electricity_price_statistics] Accessed 28.3.2018

Eurostat (2018a) Renewable energy statistics, Eurostat statistics explained. Web resource. [URL: http:// ec.europa.eu/eurostat/statistics-explained/index.php/Renewable_energy_statistics] Accessed 16.8.2018.

Eurostat (2018b) Real GDP growth rate - volume - Percentage change on previous year. Web resource. [URL:

http://ec.europa.eu/eurostat/tgm/table.do? $\underline{\mathrm{tab}}=$ table\&init $=1 \&$ language $=$ en $\&$ pcode $=$ tec00115\&plugin $=1]$ Accessed 30.8.2018

Evensen, D., Jacquet, J.B., Clarke, C.E., Stedman, R.C. (2014) What's the 'fracking' problem? One word can't say it all, The Extractive Industries and Society, vol. 1, iss. 2, pp. 130-136. https://doi.org/10.1016/j.exis.2014.06.004

Facebook (2017) Sustainability - Adding clean and renewable energy to the grid. Web page. [URL: https://sustainability.fb.com/clean-and-renewable-energy/\#page] Accessed 20.6.2018.

Fajardy, M., Mac Dowell, N. (2018) The energy return on investment of BECCS: is BECCS a threat to energy security?, Energy \& Environmental Science, vol. 11., pp. 1581-1594. https://doi.org/10.1039/C7EE03610H

Federal Ministry for Sustainability and Tourism of Austria (2018) \#mission2030 - Austrian Climate and Energy Strategy, Vienna, September 2018. [URL:

https://mission2030.info/wp-content/uploads/2018/10/Klima-Energiestrategie_en.pdf] Accessed 19.11.2018.

Feltrin, A., Freundlich, A. (2008) Material considerations for terawatt level deployment of photovoltaics, Renewable Energy, vo. 33, iss. 2, pp. https://doi.org/10.1016/j.renene.2007.05.024

Ferraro, F., Etzion, D., Gehman, J. (2015) Tackling Grand Challenges Pragmatically: Robust Action Revisited, Organization Studies, vol. 36, iss. 3. pp. 363-390. https://doi.org/10.1177/0170840614563742

Frankfurt School (2018) Global Trends in Renewable Energy Investment 2018, Frankfurt School UNEP Collaborating Centre, Frankfurt School of Finance \& Management, Frankfurt. [Available online: https://drive.google.com/file/d/1SmhaI-WAcmEMqR8R9oL5Fxn0cZ0kfY8Z/view] Accessed 30.8.2018.

Fritsche, U.R., Berndes, G., Cowie, A.L., Dale, V.H., Kline, K.L., Johnson, F.X., Langeveld, H., Sharm, N., Watson, H., Woods, J. (2017) Energy and land use - Global land outlook working paper, UNCCD/IRENA. [URL: https://static1.squarespace.com/static/5694c48bd82d5e9597570999/t/ 593a4294b8a79b4be75f6078/1496990366441/Energy+and+Land+Use U Fritsche.pdf] Accessed 3.9.2018.] Accessed 3.9.2018. 
Gaudard, L., Romerio, F. (2014) The future of hydropower in Europe: Interconnecting climate, markets and policies, Environmental Science \& Policy,

vol. 37, March 2014, pp. 172-181.https://doi.org/10.1016/j.envsci.2013.09.008

Gerbens-Leenes, W., Hoekstra, A.Y., van der Meer, T.H. (2009) The water footprint of bioenergy, Proceedings of the National Academy of Sciences of the United States of America, Vol. 106, iss. 25, pp. 10219-10223. https://doi.org/10.1073/pnas.0812619106

Global Carbon Project (2018) Global Carbon Budget 2017. Online infographic. [URL:

http://www.globalcarbonproject.org/carbonbudget/17/files/Infographic_Emissions2017.png] Accessed 28.3.2018.

Goffman, E. (1974) Frame Analysis: An Essay on the Organization of Experience. New York: Harper Colophon.

Google (2017) 100\% renewable is just the beginning. Web page post. [URL: https://environment.google/projects/announcement-100/] Accessed 30.8.2018.

Grandell, L., Höök, M. (2015) Assessing Rare Metal Availability Challenges for Solar Energy Technologies, vol. 7, pp 11818-11837. https://doi.org/10.3390/su70911818

Granqvist, N., Laurila, J. (2011) Rage against self-replicating machines: framing science and fiction in the US nanotechnology field, Organization Studies, Vol. 32, No. 2, p. 253-280.

https://doi.org/10.1177/0170840610397476

Grodal, S., O’Mahony, S. (2017) How does a grand challenge become displaced? Explaining the duality of field mobilization, Academy of Management Journal 2017, vol. 60, no. 5, pp. 1801-1827. https://doi.org/10.5465/amj.2015.0890

Habib, K., Wenzel, H. (2014) Exploring rare earths supply constraints for the emerging clean energy technologies and the role of recycling, Journal of Cleaner Production, vol. 84, December 2014, pp. 348-359. https://doi.org/10.1016/j.jclepro.2014.04.035

Hajer, M., Versteeg, W., (2005) A decade of discourse analysis of environmental politics: achievements, challenges, perspectives. J. Environ. Policy Plann. 7 (3), 175-184. http://dx.doi.org/10.1080/15239080500339646.

Heard, B.P., Brook, B.W., Wigley, T.M.L., Bradshaw, C.J.A. (2017) Burden of proof: a comprehensive review of the feasibility of $100 \%$ renewable-electricity systems, Renewable and Sustainable Energy Reviews, vol. 76, September 2017, pp. 1122-1133. https://doi.org/10.1016/j.rser.2017.03.114

Heuberger, C.F., Dowell, N.M. (2018) Real-world challenges with a rapid transition to $100 \%$ renewable power systems, Joule, vol. 2, iss. 3, pp. 367-370. https://doi.org/10.1016/j.joule.2018.02.002

Hirsch, P. M., Levin, D.Z. (1999) Umbrella advocates versus validity police: a life-cycle model, Organization Science, vol. 10, iss. 2, pp.199-212. https://doi.org/10.1287/orsc.10.2.199 
Hirschberg, S., Bauer, C., Burgherr, P., Cazzoli, E., Heck, T., Spada, M., Treyer, K. (2016) Health effects of technologies for power generation: contributions from normal operation, severe accidents and terrorist threat, Reliability Engineering and System Safety, vol. 145, pp. 373-387.

https://doi.org/10.1016/j.ress.2015.09.013

Ho, S.S., Leong, A.D., Looi, J., Chen, L., Pang, N., Tandoc, E. Jr (2018) Science Literacy or Value Predisposition? A Meta-Analysis of Factors Predicting Public Perceptions of Benefits, Risks, and Acceptance of Nuclear Energy, Environmental Communication. Published online: 03 Jan 2018. https:// doi.org/10.1080/17524032.2017.1394891

Howarth, R.W. (2014) A bridge to nowhere: methane emissions and the greenhouse gas footprint of natural gas, Energy Science \& Engineering, vol. 2, iss. 2, pp. 47-60. https://doi.org/10.1002/ese3.35

IEA (2017a) World Energy Balances 2017. Paris, France.

IEA (2017b) IEA finds $\mathrm{CO}_{2}$ emissions flat for third straight year even as global economy grew in 2016, news article, 17 March 2017. [URL: https://www.iea.org/newsroom/news/2017/march/iea-finds-co2emissions-flat-for-third-straight-year-even-as-global-economy-grew.html] Accessed 28.3.2018

IEA (2017c) Tracking Progress: Natural gas-fired power, Tracking Clean Energy Progress 2017. [URL: https://www.iea.org/etp/tracking2017/naturalgas-firedpower/] Accessed 24.8.2018.

IEA (2018a) Addressing climate change - Policies and measures database. [URL:

https://www.iea.org/policiesandmeasures/climatechange/] Accessed 16.11.2018

IEA (2018b) IEA FAQ on Renewable energy. [URL:

https://www.iea.org/about/faqs/renewableenergy/] Accessed 4.4.2018

IETA (2015) Overlapping Policies with the EU ETS, July 2015, International Emissions Trading Association. [URL:

https://www.ieta.org/resources/EU/IETA_overlapping_policies_with_the_EU_ETA.pdf] Accessed 16.11.2018.

Immerzee, D.J., Verweij, P.A., André, P.C.F. (2014) Biodiversity impacts of bioenergy crop production: a state-of-the-art review, GCB Bioenergy, vol.6, iss. 3, pp. 183-209, https://doi.org/10.1111/gcbb.12067

INGAA (2016) Natural gas \& Renewables: Working together. Leaflet. [URL:

https://www.ingaa.org/File.aspx?id=30374\&v=4aeed63b\&source=generalSearch] Accessed 19.11.2018.

INGAA (2018) Natural Gas and Renewables: the Dynamic Duo, web article, 24.1.2018. [https://www.ingaa.org/AEL/AELBlog/33818.aspx?source=generalSearch] Accessed 19.11.2018.

IPCC (2018) Summary for Policymakers. In: Global warming of $1.5^{\circ} \mathrm{C}$. An IPCC Special Report on the impacts of global warming of $1.5^{\circ} \mathrm{C}$ above pre-industrial levels and related global greenhouse gas 
emission pathways, in the context of strengthening the global response to the threat of climate change, sustainable development,

and efforts to eradicate poverty [V. Masson-Delmotte, P. Zhai, H. O. Pörtner, D. Roberts, J. Skea, P. R. Shukla, A. Pirani, W. Moufouma-Okia, C. Péan, R. Pidcock, S. Connors, J. B. R. Matthews, Y. Chen, X. Zhou, M. I. Gomis, E. Lonnoy, T. Maycock, M. Tignor, T. Waterfield (eds.)]. World Meteorological Organization, Geneva, Switzerland, $32 \mathrm{pp}$.

IRENA (2016), Renewable Energy benefits: Decentralised Solutions in the Agri-food Chain, The International Renewable Energy Agency, Abu Dhabi.

IRENA (2017), Renewable energy benefits: Leveraging local capacity for solar PV, The International Renewable Energy Agency, Abu Dhabi.

IRENA (2018) IRENA Membership, web site. [URL: http://www.irena.org/irenamembership] Accessed 29.5.2018.

Jacobson, M.Z., Delucchi, M.A. (2011) Providing all global energy with wind, water, and solar power, Part I: technologies, energy resources, quantities and areas of infrastructure, and materials, Energy Policy, vol. 39, iss. 3, pp. 1154-1169 https://doi.org/10.1016/j.enpol.2010.11.040

Jacobson, M.Z., Delucchi, M.A., Bauer, Z.A.F, Goodman, S.C., Chapman, W.E., Cameron, M.A., Bozonnat, C., Chobadi, L., CLonts, H.A., Enevoldsen, P., Erwin, J.R., Fobi, S.N., Goldstrom, O.K., Hennessy, E.M., Liu, J., Lo, J., Meyer, C.B., Morris, S.B., Moy, K.R., O’Neill, P.L., Petkov, I., Redfern, S., Schuker, R., Sontag, M.A., Wang, J., Weiner, E., Yachanin, A.S. (2017) 100\% Clean and Renewable Wind, Water, and Sunlight All-Sector Energy Roadmaps for 139 Countries of the World, Joule, vol. 1, iss.1, pp. 108-121. https://doi.org/10.1016/j.joule.2017.07.005

Jessup, B. (2010) Plural and hybrid environmental values: a discourse analysis of the wind energy conflict in Australia and the United Kingdom, Environmental Politics, vol. 19, iss. 1, pp. 21-44. https:// doi.org/10.1080/09644010903396069

Jordan-Korte, K. (2011) Government Promotion of Renewable Energy Technologies Policy Approaches and Market Development in Germany, the United States, and Japan. Springer Gabler, ISBN 978-3-8349-6587-5.

Kallio, A. M. I., Salminen, O., Sievänen, R. (2013). Sequester or substitute-consequences of increased production of wood based energy on the carbon balance in Finland. Journal of Forest Economics, vol 19, iss. 4, pp. 402-415. https://doi.org/10.1016/j.jfe.2013.05.001

Kates, R.W., Parris, T.M., Leiserowitz, A.A. (2005) Editorial - What is sustainable development? Goals, indicators, values, and practice, Environment: Science and Policy for Sustainable Development, vol. 47., iss. 3, pp. 8-21. https://doi.org/10.1080/00139157.2005.10524444

Kim, Y., Kim, W., Kim, M. (2014) An international comparative analysis of public acceptance of nuclear energy, Energy Policy, vol. 66, pp. 475-483. https://doi.org/10.1016/j.enpol.2013.11.039 
Kirk, A. (2001). Appropriating Technology: The whole earth catalog and counterculture environmental politics, Environmental History, vol. 6, no.3, pp. 374-394. https://doi.org/ 10.2307/3985660

Knopf et al. (2015) Germany's nuclear phase-out: sensitivities and impacts on electricity prices and $\mathrm{CO}_{2}$ emissions, Economics of Energy \& Environmental Policy, vol. 3, no. 1, p. 89-106. http://www.jstor.org/stable/26189266

Kumar, A., Schei, T., Ahenkorah, A., Caceres Rodriguez, R., Devernay, J.-M., Freitas, M. , Hall, D., Killingtveit, Å., Liu, Z. (2011) Hydropower. In IPCC Special Report on Renewable Energy Sources and Climate Change Mitigation [O. Edenhofer, R. Pichs-Madruga, Y. Sokona, K. Seyboth, P. Matschoss, S. Kadner, T. Zwickel, P. Eickemeier, G. Hansen, S. Schlömer, C. von Stechow (eds)], Cambridge University Press, Cambridge, United Kingdom and New York, NY, USA.

Littlefield, S.R. (2013) Security, independence, and sustainability: imprecise language and the manipulation of energy policy in the United States, Energy Policy, vol. 52, January 2013, pp. 779-788. https://doi.org/10.1016/j.enpol.2012.10.040

Lovins, A. (1976). Energy strategy: the road not taken. Foreign Affairs, vol. 55, no. 1, pp. 65-96. https://doi.org/10.2307/20039628

Matthes, F.C., Haller, M., Loreck, C., Cook, V. (2015) Die Umlage des ErneuerbarenEnergienGesetzes (EEG). Hintergründe, Trends, Treiber und Perspektiven. (In German, with English summary). Öko-Insitut, Berlin, Germany. [URL:https://www.oeko.de/oekodoc/2448/2015-605-de.pdf] Accessed 3.9.2018.

Ministry of Economic Affairs and Employment (2018) Legislative proposals: coal ban in 2029, more transport biofuels and more biofuel oil for heating and machinery, Press release 18.10.2018. [URL: https://tem.fi/en/article/-/asset publisher/lakiehdotukset-kivihiilikielto-2029-lisaa-biopolttoaineitaliikenteeseen-seka-biopolttooljya-lammitykseen-ja-tyokoneisiin] Accessed 16.11.2018.

Moriarty, P., Honnery, D. (2012) What is the global potential for renewable energy?, Renewable and Sustainable Energy Reviews, vol. 16, pp. 244-252. https://doi.org/10.1016/j.rser.2011.07.151

Naegler, T., Simon, S., Klein, M., Gils, H.C. (2015) Quantification of the European industrial heat demand by branch and temperature level, International Journal of Energy Research, vol. 39, iss. 15, pp. 2019-2030. https://doi.org/10.1002/er.3436

Nordic Energy Research (2016) Nordic Energy Technology Perspectives 2016 - Cities, flexibility and pathways to carbon-neutrality, Nordic Energy Research, Norway. [URL: http://www.nordicenergy.org/ wp-content/uploads/2016/04/Nordic-Energy-Technology-Perspectives-2016.pdf] Accessed 31.8.2018

OECD/IEA (2010) Energy poverty - How to make modern energy access universal? Special early excerpt of the World Energy Outlook 2010 for the UN General Assembly on the Millennium Development Goals. International Energy Agency, Paris, France, [URL: http://www.undp.org/content/dam/aplaws/publication/en/publications/environment-energy/www-ee- 
library/sustainable-energy/energy-poverty-how-to-make-modern-energy-access-universal/ Energy_Poverty_Excerpt_WEO2010.pdf] Accessed 3.9.2018.

OECD (2011) Interactions Between Emission Trading Systems and Other Overlapping Policy Instruments, General Distribution Document, Environment Directorate, OECD, Paris.

O’Neill, S.J, Smith, N. (2014) Climate change and visual imagery, WIREs Clim Change, vol. 5, pp. 7387. https://doi.org/10.1002/wcc.249

Oroschakoff, K. (2018) Germany's green energy shift is more fizzle than sizzle, Politico. 23.3.2018. [URL:https://www.politico.eu/article/germany-climate-change-green-energy-shift-is-more-fizzle-thansizzle/] Accessed 31.8.2018.

Pearce, F. (1991). Green Warriors: The People and the Politics Behind the Environmental Revolution. London: The Bodley Head.

Pearce, F. (2008) Time to bury the 'clean coal' myth, The Guardian, 30.10.2000. [URL:

https://www.theguardian.com/environment/2008/oct/30/fossilfuels-carbonemissions] Accessed 1.6.2018

Pedroli, B., Elbersen, B., Frederiksen, P., Grandin, U., Heikkilä, R., Henning Krogh, P., Izakovicova, Z., Johansen, A., Meiresonne, L., Spijker, J. (2013) Is energy cropping in Europe compatible with biodiversity? - Opportunities and threats to biodiversity from land-based production of biomass for bioenergy purposes, Biomass and Bioenergy, vol. 55, pp. 73-86. https://doi.org/10.1016/j.biombioe.2012.09.054

Plessmann, G., Ermann, M., Hlusiak, M., Breyer, C. (2014) Global Energy Storage Demand for a 100\% Renewable Electricity Supply, Energy Procedia, vol. 46, pp. 22-31.. https://doi.org/10.1016/j.egypro.2014.01.154

Prindle, B., Eldridge, M., Eckhardt, M., Frederick, A. (2007) The Twin Pillars of Sustainable Energy: Synergies between Energy Efficiency and Renewable Energy Technology and Policy. ACEEE Report Number E074, American Council for an Energy-Efficient Economy.

Pöyry Management Consulting (2018) Impact assessment of banning coal use - report to the Ministry of Economic Affairs and Employment of Finland (in Finnish). [URL:

https://tem.fi/documents/1410877/2132296/Selvitys_++Kivihiilen+kielt\%C3\%A4misen+vaikutukset/ 8fb510b4-cfa3-4d9f-a787-0a8a4ba23b5f/Selvitys_++Kivihiilen+kielt\%C3\%A4misen+vaikutukset.pdf] Accessed 16.11.2018.

RE100 (2018) RE100 website. [URL: http://there100.org/] Accessed 3.9.2018.

Rosenberg, N. (1976). Perspectives on Technology. Cambridge, UK: Cambridge University Press. 
Rybach, L. (2007) Geothermal sustainability, Geo-heat Center Quarterly Bulletin, vol. 28, no. 3. pp. 27. [URL: https://www.oit.edu/docs/default-source/geoheat-center-documents/quarterly-bulletin/vol28/28-3/28-3-bull-all.pdf?sfvrsn=4] Accessed 31.8.2018.

Sanderson, B.M., O'Neill, B.C., Tebaldi, C. (2016) What would it take to achieve the Paris temperature targets?, Geophys. Res. Lett., vol. 43, iss. 13, pp. 7133-7142, https://doi.org/10.1002/2016GL069563.

Schumacher, E. F. (1973). Small is Beautiful. A Study of Economics as if People Mattered. London: Blond and Briggs.

Schüssler, E., Rüling, C.-C., Wittneben, B.B.F. (2014) On melting summits: The limitations of fieldconfiguring events as catalysts of change in transnational climate policy, Academy of Management Journal, vol. 57, no. 1, pp. 140-171. https://doi.org/10.5465/amj.2011.0812

Schwietzke, S., Sherwood, O.A., Bruhwiler, L.M.P., Miller, J.B., Etiope, G., Dlugokencky, E.J., Englund Michel, S., Arling V.A., Vaugh, B.H., White, J.W.C., Tans, P.P. (2016) Upward revision of global fossil fuel methane emissions based on isotope database, Nature,538, pp. 88-91. https://doi.org/10.1038/nature19797

Schoeder A., Oei, P-Y., Sander, A., Hankel. L., Laurisch, L.C. (2013) The integration of renewable energies into the German transmission grid-A scenario comparison, Energy Policy, Vol. 61, pp. 140150. https://doi.org/10.1016/j.enpol.2013.06.006

Scott, W.R. (1995) Institutions and Organizations. Thousand Oaks, CA, USA.

Scott, W.R. (2008) Institutions and Organizations: Ideas and Interests, 3rd ed. Sage Publications, Los Angeles, CA, USA.

Scrase, J.I., Ockwell, D.G. (2010) The role of discourse and linguistic framing effects in sustaining high carbon energy policy - An accessible introduction, Energy Policy, vol. 38, iss. 5, pp. 2225-2233. https://doi.org/10.1016/j.enpol.2009.12.010

Siemens (2018) Heading toward a sustainable energy system, web site. [URL:

https://www.siemens.com/global/en/home/company/topic-areas/sustainable-energy.html] Accessed 29.3.2018

Sigsgaard, T., Forsberg, B., Annesi-Maesano, I., Blomberg, A., Bølling, A., Boman, C., Bønløkke, J., Brauer, M., Bruce, N., Héroux ,M.E., Hirvonen, M.R., Kelly, F., Künzli, N., Lundbäck, B., Moshammer, H., Noonan, C., Pagels, J., Sallsten, G., Sculier, J.P., Brunekreef, B. (2015) Health impacts of anthropogenic biomass burning in the developed world, Eur Respir J., vol. 46, iss. 6, pp.1577-88. https://doi.org/10.1183/13993003.01865-2014.

Slaper, T.F., Hall, T.J. (2011) The Triple Bottom Line: What Is It and How Does It Work?, Indiana Business Review. vol. 86, no. 1, p 4-8. 
Sopher, P. (2015) Lessons Learned from Germany's Energiewende: The Political, Governance, Economic, Grid Reliability, and Grid Optimization Bedrock for a Transition to Renewables, Renewable Resources Journal, vol 29, iss. 3. pp. 6-13.

Stefansson, V. (2000) The renewability of geothermal energy, Proceedings World Geothermal Congress 2000, pp. 883-888. [URL: https://www.geothermal-energy.org/pdf/IGAstandard/WGC/2000/ R0776.PDF] Accessed 3.9.2018.

Stefes, C. F. (2016) Critical Junctures and the German Energiewende, in Hager, C., Stefes, C. (eds) (2016) Germany's Energy Transition - A Comparative Perspective, Palgrave Macmillan, US. https://doi.org/10.1057/978-1-137-44288-8

Särkikoski, T. (2011). Rauhan atomi, sodan koodi: Suomalaisen atomivoimaratkaisun teknopolitiikka 1955-1970. PhD thesis, Department of History, University of Helsinki, Helsinki._ http://urn.fi/URN:ISBN:978-952-10-7287-1

Thornton, P.H., Ocasio, W. (1999) Institutional logics and the historical contingency of power in organizations: executive succession in the higher education publishing industry, 1958-1990, Am. J. Sociol, vol. 105, iss. 3, pp. 801-843. http://dx.doi.org/10.1086/210361.

Tilman, D., Cassman, K.G., Matson, P.A., Naylor, R., Polasky, S. (2002) Agricultural sustainability and intensive production practices, Nature, Vol. 418, August 2002, pp. 617-677.

http://dx.doi.org/10.1038/nature01014

Transparent Cost Database (2018) Open Energy Information (en). []URL:_ https://openei.org/wiki/Transparent_Cost_Database] Accessed 17.9.2018.

Trainer, T. (2012) A critique of Jacobson and Delucchi's proposals for a world renewable energy supply, Energy Policy, vol. 44, May 2012, pp. 476-481. https://doi.org/10.1016/j.enpol.2011.09.037

Tao, C.S., Juang, J., Tao, M. (2011) Natural resource limitations to terawatt-scale solar cells, Solar Energy Materials and Solar Cells, vol. 95, iss. 12, pp. 3176-3180.

https://doi.org/10.1016/j.solmat.2011.06.013

Teske, S. Muth, J., Sawyer, S., Pregger, T. Simon, S., Naegler, T., O’Sullivan, M., Schmid, S., Pagenkopf, J., Frieske, B., Graus, W.H.J., Kermeli, K., Zittel, W., Rutovitz, J., Harris, S., Ackermann, T., Ruwhata, R., Martense, N. (2012) Energy [r] evolution - A sustainable energy outlook, 4th edition 2012 world energy scenario. Greenpeace International, EREC and GWEC.

Umweltbundesamt (2018) Klimabilanz 2017: Emissionen gehen leicht zurück - Niedrigere Emissionen im Energiebereich, höhere im Verkehrssektor (in German). [URL: https://www.umweltbundesamt.de/presse/pressemitteilungen/klimabilanz-2017-emissionen-gehenleicht-zurueck] Accessed 3.9.2018

United Nations (1987) Report of the World Commission on Environment and Development: Our Common Future, Annex to document A/42/427 - Development and International Co-operation: Environment, United Nations. 
United Nations (2016). The Paris Agreement. Paris: United Nations. [URL:

http://unfccc.int/paris_agreement/items/9485.php] Accessed 3.9.2018.

Victor, D.G., Akimoto, K., Kaya, Y., Yamaguchi, M., Cullenward, D., Hepburn, C. (2017) Prove Paris was more than paper promises, Nature, vol. 548, iss. 7665, pp. 25-27. https://doi.org/10.1038/548025a

Vidal, O., Goffe, B., Arndt, N. (2013) Metals for a low-carbon society, Nature Geoscience, vol. 6, pp. 894-896, https://doi.org/10.1038/ngeo1993

Warner, E. S., \& Heath, G. A. (2012). Life cycle greenhouse gas emissions of nuclear electricity generation. Journal of Industrial Ecology, 16, S73-S92. https://doi.org/10.1111/j.15309290.2012.00472.x

Waters, R. (2008) Energy from Ocean Waves - Full Scale Experimental Verification of a Wave Energy Converter, Digital Comprehensive Summaries of Uppsala Dissertations from the Faculty of Science and Technology 580. [URL: https://www.diva-portal.org/smash/get/diva2:172943/FULLTEXT01.pdf] Accessed 3.9.2018.

World Energy Council (2017) World Energy Trilemma Index 2017 - Monitoring the sustainability of national energy systems, London, UK. [URL:

https://trilemma.worldenergy.org/reports/main/2017/2017\%20Energy\%20Trilemma\%20Index.pdf] Accessed 3.9.2018.

WWF (2011) The Energy Report - $100 \%$ Renewable Energy by 2050. WWF International, Gland, Switzerland. [URL: https://www.ecofys.com/files/files/ecofys-wwf-2011-the-energy-report.pdf] Accessed 3.9.2018.

Weart, S. R. (2012). The Rise of Nuclear Fear. Cambridge, MA, Harvard University Press.

Wärtsilä (2018) Wärtsilä leading along the path towards a 100\% renewable energy future, Wärtsilä Corporation Press release14 June 2018 at 10:00 AM E. Europe Standard Time.

[https://www.wartsila.com/media/news/14-06-2018-wartsila-leading-along-the-path-towards-a-100renewable-energy-future-2207856] Accessed 3.9.2018.

Zarfl, C., Lumsdon, A.E., Berlekamp, J., Tydecks, L., Tockner, K. (2015) A global boom in hydropower dam construction, Aquatic Sciences,vol. 77, iss. 1., pp. 161-170. https://doi.org/10.1007/s00027-014-0377-0

Zanchi, G., Pena, N., Bird, N. (2011) Is woody bioenergy carbon neutral? A comparative assessment of emissions from consumption of woody bioenergy and fossil fuel, GCB Bioenergy, vol. 4, iss. 6, pp. 761-772. https://doi.org/10.1111/j.1757-1707.2011.01149.x 